\title{
Assessment of Post-Harvest Loss and Waste for Date Palms in the Kingdom of Saudi Arabia
}

\author{
Prof. Mohammad Samir El-Habbab ${ }^{1}$, M.S., Al-Mulhim F. ${ }^{2}$, Al-Eid, S. ${ }^{3}$, \\ Abo El-Saad M. ${ }^{4}$, Aljassas, F. ${ }^{5}$, Sallam, A. ${ }^{6}$, Ghazzawy H. ${ }^{7}$ \\ ${ }_{1,2,3,4,6,7}$ Extension and Economics of Date Palm and its derivatives Program, King Faisal University, Kingdom of Saudi \\ Arabia \\ ${ }^{5}$ King Abdulaziz City for Science and Technology, Kingdom of Saudi Arabia
}

\begin{abstract}
Estimated dates loss at harvest time include shees \& besr, eating by birds, falling, insects and dust mite, and healthy fruits of three cultivars from the date palm orchards in al-Ahsa Oasis (Khalas, Shishi and Ruzeize), in Al-Qaseem (Sukkary, Khudry and Segae), in Madinah (Safawi, Anbara, Ajweh). In Riyadh (Khalas, Sagei and Nabtet Seif). The highest losses during harvest time in Al-Ahsa were in Khals, then comes Shishi then Ruzeize. In Qaseem, the least affected variety was Sukkari, then Khudri then Segae. In Medina, Anbara was the most affected variety then comes Safawi then Ajweh. In Riyadh, the most affect variety was Nabtet Seif then comes Khalas then Segae. The average level of loss during the marketing phase was about 5-10\% in most varieties and locations except Ajweh in Riadh ( $<5 \%)$, and Shagra in Qassem (16-20\%). The major causes of waste were the dates' small size, and cuts and browses.
\end{abstract}

Photography analysis showed that dates are dramatically affected by various pest infestation and non-pathological disorders. The average of general dates disorders or dates damages was $12.6 \%$, which represents the percentage of dates loss of most commonly ones in the major date production regions in Saudi Arabia. In addition, eleven dates variety commercially available were collected at Alahsa dates retail market which produced by the major production regions; Alahsa, Riyadh, Qaseem and Madina. The data showed that the average of general dates disorders or dates damage were the highest for Shishi and Shbibi in AlAhsa (33\%), while the lowest was for Ajweh in Medina (2.7\% only).

Keywords-Post-Harvest Loss, Waste, Date Palms, Kingdom of Saudi Arabia, harvest time.

\section{INTRODUCTION}

Saudi Arabia is one of the leading palm dates production and consumption countries, and to a lesser extent, in export, as they ranked, in 2014, third in the world in terms of production (13.9\%).

The planted area with date palm trees in the Kingdom in 2014 was about 107 thousand hectares, while the number of palm trees in the same year reached nearly 28 million palm trees. Palm trees are grown in different regions of the Kingdom, which is characterized by the diversity of climate. The most important palm growing areas are the Riyadh region, Qasim, Alahsa and Medina. General. Authority of Statistics, (2015).

New date palm plantations are established in the Kingdom of Saudi Arabia (KSA) which will cause an increase in dates' production which necessitates the adoption of more efficient post-harvest handling, marketing and processing. Dates in the gulf area are considered a backbone for food security and water security in these countries, so it is very important to decrease the level of waste and loss in this sector.

The major problem of the production of dates in the KSA is related to dates processing, where about $7.4 \%$ of the production only is processed, though, mainly packing activities, using unspecialized equipment in the field of date sector, but they are also used for other fruits, and therefore the quality is not at the required level.

(Gustavsson et al., 2011) defined post-harvest loss as the decrease of edible food throughout the supply chain that leads to the decrease of edible food for human consumption, while waste refers to the loss at the end of the food chain, i.e. retail and final consumption.

Kitinoja (2016) summarized causes of food loss and waste in the following: a) absence or weaknesses of quality standards, b) Surplus in supply of food c) Lack of appropriate storage facilities, d) deficiency in packing material. Another study was conducted on Harvesting and Post Harvesting Handling of dates to explore the causes of losses, (Kader and Hussein, 2009), where they showed that the main causes of high postharvest losses were fermentation, insect infestation, birds, and mechanical damage. 
Food quality is affected by climate conditions such as temperature and light intensity. Moreover, soil type, the rootstock used for fruit trees, mulching, irrigation, fertilization, and other cultural practices affects directly the level of losses in the crops. (Kader, 2012). Post-harvest loss and waste of dates are caused, among other factors, by insects, mites, birds, rats, mollusks and bats or flying foxes. There are other factors that increase dates losses such as physical damages during harvesting, handlings, incidence of physical and physiological disorders and pathogens also contribute to the losses. The date palm farms in The Gulf Cooperation Countries (GCC), mainly in KSA, are characterized by high post-harvest losses due to fermentation, insect infestation, birds and mechanical damage. So as to reduce post-harvest losses it is suggested to improve food security and returns to investment in agricultural research, which will lead to lower food prices, and higher food availability. Rosegrant et. al. (2016). Moreover, loss in food products is considered as loss in resources that produce them, noticing that in these resources such as suitable land and water are limited. Beretta et. al. (2013).

A study conducted by AlQurash (2012) found that pre-harvest fruit drop is a serious problem of some date palm cultivars growing in hot arid regions in Saudi Arabia. Another study was conducted on Harvesting and Post Harvesting Handling of Dates (Kader and Hussein, 2009), they found that there is a need to decrease the postharvest losses caused by fungi, insects, birds, cuts and browses.

In Saudi Arabia, field storage of dates and sun drying, as it is the case in many date-producing countries, subject date to infestation by stored-product insects. Insects cause quantitative and qualitative losses of dates through changing chemical composition, and subsequently, the nutritive value of dates (Scott, 1991).

Insect infestations of dates are most likely started from the field based on certain organic volatile compounds (OVC) from mature stage of dates which paly a fundamental role in insect attraction. The major insect pests attack dates either on the palm tree or during sun drying of dates in field, standing dates awaiting transportation, in storehouses, factories and packing houses. Accordingly, to prevent such infestation in the field and during transit is an important angle in Integrated Pest Management (IPM) of stored dates. There are many preventive and agro-technical methods highly recommended in such respect: dates early harvesting, collect the ripe fruits firsthand and to avoid leaving it on the trees for long periods to prevent insect infestation, use of plastic netting, papers or cloths to cover fruit bunches on trees and harvested dates. Moreover, rapid transportation, clean disinfested containers and inspection of dates while on the tree. In the storehouses, precaution should have be taken: disinfestation of the storehouse using recommended pesticide, cracks sealing, repairing of doors and windows to be insect-proof. Avoidance of mixing fallen dates on the ground with clean ones. In addition, there are certain techniques to protect stored dates, fumigation of dates in storehouses by aluminum phosphide or ethyl formate, modified atmosphere, microwave technology, ozonation and biological control (Abo-El-Saad et al., 2011; Abo-El-Saad et al., 2012; Abo-El-Saad and ElShafie 2013).

This Project aims at evaluating the magnitude and causes of date palm postharvest waste and loss in the main producing areas in the KSA. Moreover, it evaluates the losses in water resource, and fertilizers used to produce these losses.

\section{METHODOLOGY}

The research was conducted through interviews using questionnaires for all date palm marketing agents, after pre-testing them. Moreover, samples of date fruits were checked for Pest Infestation (e.g. insects, fungi, mites) and Non-Pathological disorders (mechanical, birds and physiological). In addition to evaluation of the percent of the existence of Shees (Unpollinated fruits) and Besr (immature fruits during harvest time, in the main verities of dates in the kingdom.

The study covered four regions in Saudi Arabia, Al-Ahsa, Al-Qasim, Almadeah, and Al-Riyadh, since they produce more than $80 \%$ of Saudi dates.

\section{RESULTS AND DISCUSSIONS}

\subsection{Loss and Waste at Harvest time}

\subsubsection{AlAhsa Region}

Ruzaze variety gave the highest percentage of good fruits (92.36\%) with the lowest shees \& besr percentage (2.20\%). Shishi palm gave $0.6 \%$ of fruit infested with dust mite followed by Ruzaze at rate $0.37 \%$, whereas Khalas showed the highest value in this respect $(1.26 \%)$. In addition, the data revealed that Ruzaze gave the lowest value of dropping $(0.04 \%)$, while Khalas gave the highest $(4.48 \%)$. This finding could be due to covering bunches of Ruzaze in plastic sacks. The low percentage of 
good fruits of Khalas variety, and at the same time, increase of shees \& besr percentage, may be caused by some environmental condition during ripping period or deficiency of some nutrients such as potassium Table 1.

TABLE 1

LOSS AND WASTE OF DATE FruITS AT HARVEST TIME FOR SOME VARIETIES IN AlAHSA REGION \%

\begin{tabular}{|c|c|c|c|c|c|c|c|}
\hline Variety & Unaffected & Shees \& Besr & Birds & Droppings & Insects & Dust Mites & Total \\
\hline Khalas & 61.19 & 26.18 & 3.94 & 4.48 & 2.95 & 1.26 & 100 \\
\hline Shishi & 76.1 & 17.5 & 1.2 & 2.3 & 2.8 & 0.1 & 100 \\
\hline Ruzaze & 92.36 & 2.2 & 3.4 & 0.04 & 1.63 & 0.37 & 100 \\
\hline
\end{tabular}

Source: Field Survey

\subsubsection{Al-Qasim Region}

The quality of the selected cultivars in AlQasim was better than in AlAhsa. The majority (more than 98\%) of the produce of the three selected varieties were found healthy. Sukkary gave the highest percentage of healthy fruits compared with Khudry and Segae (99.23\%, 98.57\% and 97.92\% respectively). Segae produced highest value of sheees \& bisr compared with Khudry and Sukkary.

In Khudary variety, Shees \&Besr is considered as the higher percentage in yield loss $(0.75 \%)$ then comes fruit droppings $(0.3 \%)$ then insects $(0.28 \%)$. In the Segae variety. Shees contributed the highest level of loss $(1.19 \%)$, while birds and fruit droppings constituted about $0.43 \%$ and $0.35 \%$ of the loss respectively. Table 2

\section{TABLE 2}

LOSS AND WASTE OF DATE FrUITS AT HARVEST TIME FOR SOME VARIETIES IN AL-QASIM REGION \%

\begin{tabular}{|c|c|c|c|c|c|c|c|}
\hline Variety & Unaffected & Shees\&Besr & Birds & Droppings & Insects & Dust Mites & Total \\
\hline Sukkary & 99.23 & 0.45 & 0.07 & 0.01 & 0.15 & 0.09 & 100 \\
\hline Khudari & 98.58 & 0.75 & 0.08 & 0.3 & 0.28 & 0.01 & 100 \\
\hline Segie & 97.93 & 1.19 & 0.43 & 0.35 & 0.1 & 0.0 & 100 \\
\hline
\end{tabular}

Source: Field Survey

\subsubsection{Al-Madena Region}

The healthy dates' fruits in Madena constituted about $95.14 \%$ of the samples of Ajweh, while they constituted about $89.53 \%$ and $82.54 \%$ in Safawi and Anbara varieties respectively. The level of loss for Anbara variety was due to sheees \&besr $(12.22 \%)$ then comes birds and Dust Mites (2.73\% and $2.05 \%$ respectively). On the other hand, that the highest two sources of loss in Ajweh variety were shees \&besr and birds (2.88\% and $1.83 \%$ respectively). Table 3

\section{TABLE 3}

LOSS AND WASTE OF DATE Fruits AT HARVEST TIME FOR SOME VARIETIES IN Al-MADENA REGION \%

\begin{tabular}{|l|c|c|c|c|c|c|c|}
\hline Variety & Unaffected & Shees \& Besr & Birds & Droppings & Insects & Dust Mites & Total \\
\hline Ajweh & 95.14 & 2.88 & 1.82 & 0.15 & 0.01 & 0 & 100 \\
\hline Safawi & 89.53 & 4.67 & 2.91 & 1.92 & 0.21 & 0.76 & 100 \\
\hline Anbara & 82.54 & 12.22 & 2.73 & 0.43 & 0.03 & 2.05 & 100 \\
\hline
\end{tabular}

Source: Field Survey

\subsubsection{Riyadh Region}

The healthy dates' fruits in Riyadh constituted about $90.65 \%$ of the samples of Segie, while they constituted about $76.5 \%$ and $69.49 \%$ in Khalas and Nabtet Saif varieties respectively. The level of loss for Khalas variety was due to Shees \&Besr $(18.56 \%)$ then comes birds and fruits droppings (3.91\% and $0.9 \%$ respectively). In the Segae variety in Riyad, Shees contributed the highest level of loss $(6.24 \%)$, while birds constituted about $2.98 \%$ of the loss, the other factors were not significant. On the other hand, the highest two sources of loss in Nabtet Saif variety were Shees\&Bisr and birds (18.74\% and $11.77 \%$ respectively).Table 4 


\section{TABLE 4}

LOSS AND WASTE OF DATE FRUITS AT HARVEST TIME FOR SOME VARIETIES IN RIYADH REgION \%

\begin{tabular}{|c|c|c|c|c|c|c|c|}
\hline Variety & Unaffected & Shees \& Besr & Birds & Droppings & Insects & Dust Mites & Total \\
\hline Khalas & 76.5 & 18.56 & 3.91 & 0.9 & 0.06 & 0.07 & 100 \\
\hline Segie & 90.65 & 6.24 & 2.98 & 0 & 0.06 & 0.07 & 100 \\
\hline Nabtet Seif & 69.49 & 18.74 & 11.77 & 0 & 0 & 0 & 100 \\
\hline
\end{tabular}

The Expected Causes of Damage during Harvesting could be caused by the following factors:

\section{A. Farm husbandry, environmental and physiological factors:}

- In vitro fertilization programs should be considered in all aspects in terms of the type of pollination and its efficiency after storing it through the tests of the efficiency of the pollen in the form of the Stocarmine, or through its suitability to pollinate certain varieties. Sometimes there is a state of incompatibility or less fruit formulation percentages causing "Shees". This could be caused by the fact that pollination period is not suitable for receiving pollen or because of the inefficiency of the pollination process or lack of interest in the re-pollination procedure for this period in windy days, so the pollen may not reach the female flowers or washed due to rain because this period is a period of atmospheric fluctuations.

- The high rate of damage in date palms is could be due to the fact that it is a perishable crop after harvest and has limited shelf life or storage. To reduce the loss of date palms after harvest, while maintaining quality as long as possible, first the farmer must be fully aware of the factors of deterioration after the harvest and to know ways and means and techniques to control it.

\section{B. Internal deterioration factors}

a. Physiological damage:

- One of the factors of internal degradation that arises from exposure to inappropriate factors before or after harvest, such as food imbalance prior to harvest due to lack of calcium and potassium. Applying calcium and potassium before harvest reduces the chance of the fruits being exposed to such damage and increases their storage capacity.

- $\quad$ The fruits are exposed to many physiological damage due to poor post-harvest storage conditions such as cold damage and high heat damage. In addition to many other physiological damage caused by the imbalance of gases in the atmosphere surrounding the fruits.

- In order to avoid such physiological damage, attention must be paid to agricultural operations prior to harvest, through harvesting and handling, and to optimal storage conditions.

\section{External Degradation Factors:}

Some of the factors that affect fruits after harvest include temperature, relative humidity, and light, etc. in addition to exposure to mechanical damage and injuries, which will be addressed to their importance as follows:

\section{Mechanical Damage:}

The fruits are exposed during harvesting, handling, packing and transport for scraping, scratching and falling from different heights. Such mechanical damage leads to the aging of the fruit as quality deteriorates. It is also accompanied by a high rate of respiration and a high rate of loss of their internal moisture. Surface mechanical damage also allows for the growth of many fungi and bacteria, which increases the percentage of rotting fruits during marketing or storage and thus increase the percentage of damage in quantity and quality.

\section{E. Diseases:}

Disease is one of the most important factors of the deterioration of the fruits after harvest, and arises from the activity of fungi and bacteria, especially when the high proportion of mechanical defection and non-cleansing or rapid cooling and lack of care of refrigerated storage. There are also some diseases that can result from attacking of the fruits by some microorganisms having mechanical injuries on their outer surfaces. 


\subsection{Loss and Waste during Marketing}

Table 5 summarizes the level of waste information provided by the farmers in the four locations for ten varieties at farm level, which include the loss after harvest. About two thirds of the sample in Qasim reported a waste level of 5-10\%, while in Riyadh more than half of them reported a waste level of more than $20 \%$. Berhi variety followed almost the same pattern as Sukkari in Qasseem and Riyadh. On the other hand, most of the farmers in Qasim and Riyadh who produces Khalas variety reported a waste level of $\quad 5-10 \%$ while the majority of the farmers $(79 \%)$ in AlAhsa reported a waste level of about less than 5\% of that variety. All farmers who produce Ajweh variety reported that the level of waste level was 5-10\%, while Riyadh farmers who produce Ajweh variety reported that the level of waste was less than 5\%.

About 75\% and 67\%, respectively, of Rothana farmers in Qasim and Madena reported that the level of waste is 5-10\%. Segie Variety followed the same pattern as Rothana. While all Nabtet saif farmers in Riyad reported a waste level of 5-10\%. On the other hand the farmers who produce Shagra variety in Riyadh reported a waste level of less than 5\%

\section{TABLE 5}

LEVEL OF LOSS OF SELECTED VARIETIES IN SELECTED LOCATIONS (\%)

\begin{tabular}{|c|c|c|c|c|c|c|c|}
\hline \multirow{2}{*}{ Variety } & \multirow{2}{*}{ Location } & \multicolumn{5}{|c|}{ Percentage Waste } & \multirow{2}{*}{ Total } \\
\hline & & $<5$ & $5-10$ & 11-15 & $16-20$ & $>20$ & \\
\hline \multirow[t]{2}{*}{ Sukkari } & Qasim & 3 & 69 & & 9 & 19 & 100 \\
\hline & Riyadh & 14 & 15 & 14 & & 57 & 100 \\
\hline \multirow{2}{*}{ Berhi } & Qasim & 6 & 65 & & & 29 & 100 \\
\hline & Riyadh & & 12 & 18 & 6 & 64 & 100 \\
\hline \multirow[t]{3}{*}{ Khalas } & Qasim & 4 & 88 & & 4 & 4 & 100 \\
\hline & AlAhsa & 79 & 19 & 2 & & & 100 \\
\hline & Riyadh & 24 & 76 & & & & 100 \\
\hline \multirow[t]{3}{*}{ Aqweh } & Qasim & & 100 & & & & 100 \\
\hline & Medinah & & 100 & & & & 100 \\
\hline & Riyadh & 100 & & & & & 100 \\
\hline \multirow[t]{2}{*}{ Rothana } & Qasim & 17 & 75 & & 8 & & 100 \\
\hline & Madenah & 33 & 67 & & & & 100 \\
\hline \multirow[t]{2}{*}{ Segie } & Qasim & & 78 & & 11 & 11 & 100 \\
\hline & Riyadh & 30 & 70 & & & & 100 \\
\hline \multirow[t]{2}{*}{ Nabtet Saif } & Qasim & & 67 & & 33 & & 100 \\
\hline & Riyadh & & 100 & & & & 100 \\
\hline \multirow[t]{3}{*}{ Shagra } & Qasim & & & & 100 & & 100 \\
\hline & AlAhsa & 60 & 40 & & & & 100 \\
\hline & Riyadh & 100 & & & & & 100 \\
\hline \multirow{2}{*}{ Ruzaze } & AlAhsa & 73 & 9 & & 9 & 9 & 100 \\
\hline & Riyadh & 60 & 40 & & & & 100 \\
\hline \multirow[t]{2}{*}{ Khudri } & Qasim & & 100 & & & & 100 \\
\hline & Riyadh & 50 & 50 & & & & 100 \\
\hline
\end{tabular}

Source: Field Survey

Table 6 shows the source of loss in eight varieties in the four location. In Sukkari variety, small size constituted one third of the sources for loss while in Riyadh, cuts and browses constituted two thirds of the cause of loss. The small size of Berhi in Qasim constituted about one half of loss causes while cuts and prowess constituted about half the loss causes in Riyadh. The insects were the major cause of loss in Alahsa for Khalas variety (87\%). Moreover, insects were the major causes of loss in Khudry in Qasim (60\%).

Table 5.10, also shows that the major cause of loss for all the selected varieties was cuts and browses (about $48 \%$ ), then comes size then insects (24\% and $18 \%$ respectively. In Qasim, size is considered the main factor of loss for all the studied varieties in the region (39\%), while about $21 \%$ of loose causes in this region is caused by cuts and browses, and the same percentage for insects.

The main factor of loss in Riyadh was cuts and browses (57\%) then comes size (31\%). In AlAhsa, the main cases of loss were insects (76\%), while in Medina, only cuts and browses causes loss (100\%). 
On the other hand, the main cause of loss for Sukkai in all the regions was cuts and browses (63\%), then comes size (21\%) then insects (12\%). The same pattern was found for Berhi, i.e. cuts and browses cased loss by $54 \%$, while size and insects cased loss by $30 \%$ and $12 \%$ respectively. An insect were considered the main causes for loss in Khalas Variety (43\%) then comes size then cuts and browses (23\% and $21 \%$ respectively).

As for the mode of transportation, most of the farmers use pickups called Dyanawith a carrying capacity of 5 tons, and since the distance between the farms and the market is relatively short, these farmers said that there is no loss during transportation, except for Segei (about 22.5\%).

The loss during Storing the products were recorded for three varieties only, they are: 5\% for Sukkari, 7.5\% for Khalas, and $2.4 \%$ for Khudri.

TABLE 6

SOURCES OF LOSS IN THE SELECTED VARIETIES IN THE STUDY AREA (\%)

\begin{tabular}{|c|c|c|c|c|c|c|c|c|}
\hline \multirow{2}{*}{ Variety } & \multirow{2}{*}{ Location } & \multicolumn{6}{|c|}{ Sources of Loss for Selected Varieties } & \multirow{2}{*}{ Total } \\
\hline & & Size & $\begin{array}{l}\text { Cuts And } \\
\text { Browses }\end{array}$ & Insects & Color & $\begin{array}{c}\text { Buyer } \\
\text { Refusal }\end{array}$ & Others & \\
\hline \multirow{3}{*}{ Sukkari } & Qasim & 31 & 28 & 28 & 6 & 3 & 3 & 100 \\
\hline & Reyadh & 31 & 62 & 8 & & & & 100 \\
\hline & Madena & & 100 & & & & & 100 \\
\hline \multirow{3}{*}{ Berhi } & Qasim & 52 & 12 & 24 & & 6 & 6 & 100 \\
\hline & Reyadh & 37 & 50 & 13 & & & & 100 \\
\hline & Madena & & 100 & & & & & 100 \\
\hline \multirow{3}{*}{ Khalas } & Qasim & 40 & 12 & 28 & 12 & & 8 & 100 \\
\hline & Alahsa & & & 87 & & & 13 & 100 \\
\hline & Reyadh & 33 & 52 & 15 & & & & 100 \\
\hline \multirow{2}{*}{ Ajweh } & Qasim & & 50 & 25 & & & 25 & 100 \\
\hline & Reyadh & 33 & 67 & & & & & 100 \\
\hline \multirow[t]{2}{*}{ Rothana } & Qasim & 28 & 18 & 27 & 9 & & 18 & 100 \\
\hline & Reyadh & 30 & 50 & 20 & & & & 100 \\
\hline \multirow{3}{*}{ Segie } & Qasim & 45 & & 22 & 11 & 11 & 11 & 100 \\
\hline & Reyadh & 53 & 42 & & & & 5 & 100 \\
\hline & Madina & & 75 & & & & 25 & 100 \\
\hline \multirow{2}{*}{ Ruzaze } & Alahsa & & 18 & 64 & & & 18 & 100 \\
\hline & Reyadh & & 80 & 20 & & & & 100 \\
\hline \multirow{3}{*}{ Nabtet Saif } & Qasim & 67 & 33 & & & & & 100 \\
\hline & Reyadh & 30 & 50 & & & & 20 & 100 \\
\hline & Madena & & 100 & & & & & 100 \\
\hline Average & & 24 & 48 & 18 & 2 & 1 & 7 & 100 \\
\hline
\end{tabular}




\subsection{Waste and Loss at Processing and Retail Levels}

This section discusses the level of waste and loss (caused by) physiological and non-pathological disorders) and loss (caused by pest infestation in date ready for sale to the consumers.

Twenty dates varieties produced in different regions in Saudi Arabia have been collected from Alahsa national date factory during the seasons 2014- 2015 (during Sep-Dec). Fig. (1) Shows the pest infestation, physiological and non-pathological disorders of dates, where insect disorders obviously shown (Fig. 1a), pathological disorders of dates caused by fungi (Fig. 1b), mite disorders (Fig. 1c), physiological disorders (Fig. 1d), bird disorders (Fig. 1 e), mechanical disorders (Fig. 1 f). These disorders of dates are represented main disorders that could be reflect the actual losses of dates caused by pest infestation results in dates damage that cannot be repaired, therefore dates loss includes; loss of weight, loss of nutrients, reduced grade, lower market value and/or contamination. The highest rates of general distortions where the highest in AlAhsa region.

Table 6 summarizes the average disorders in the selected varieties and regions. The highest level of waste and loss was in Shisi in AlAhsa (33.3\%) then comes Minifi (21.78\%) variety in Riyadh region. The lowest level of Loss was in Ajweh Variety in Madina (2.67\%), the grand average of the selected varieties was $12.19 \%$.

This data is consistent with those indicated by Kader and Hussein, (2009) who reported the importance of dates as a healthy foods and numerous pests capable to attack it (Abo-El-Saad and El-Shafie 2013).

It was found that the most causes of postharvest losses in quality and quantity are insect infestation and damage caused by insect feeding on the dates. The main insect infestation occurs by stored-products insects (such as Oryzaephilus surinamensis, Oryzaephilus mercator, Tribolium confusum, Plodia interpunctella, Cryptolestes ferrugineus, and Cadra spp.). To decrease or get rid of insect in by using forced air. On the other hand, yeast, molds and bacteria cause microbial waste.

Finally, we could conclude that pest infestation and non-pathological damages of dates were relatively high, reaching 12.19\% in dates of Saudi Arabia at both level, either dates which the government buying from farmers through national date factories or dates commercially available at dates retail marketing respectively. Therefore, management of pest attack dates and nonpathological damages, (e.g. mechanical, physiological) under pre- and post-harvesting conditions is the key element to reduce such dates disorder.
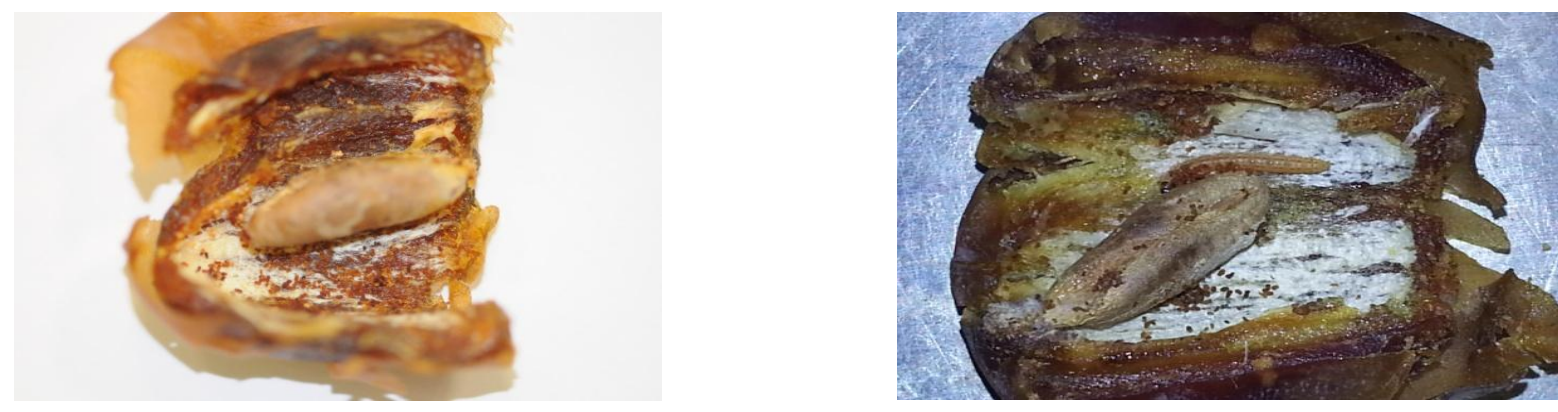

\section{INSECT DISORDERS OF DATES}
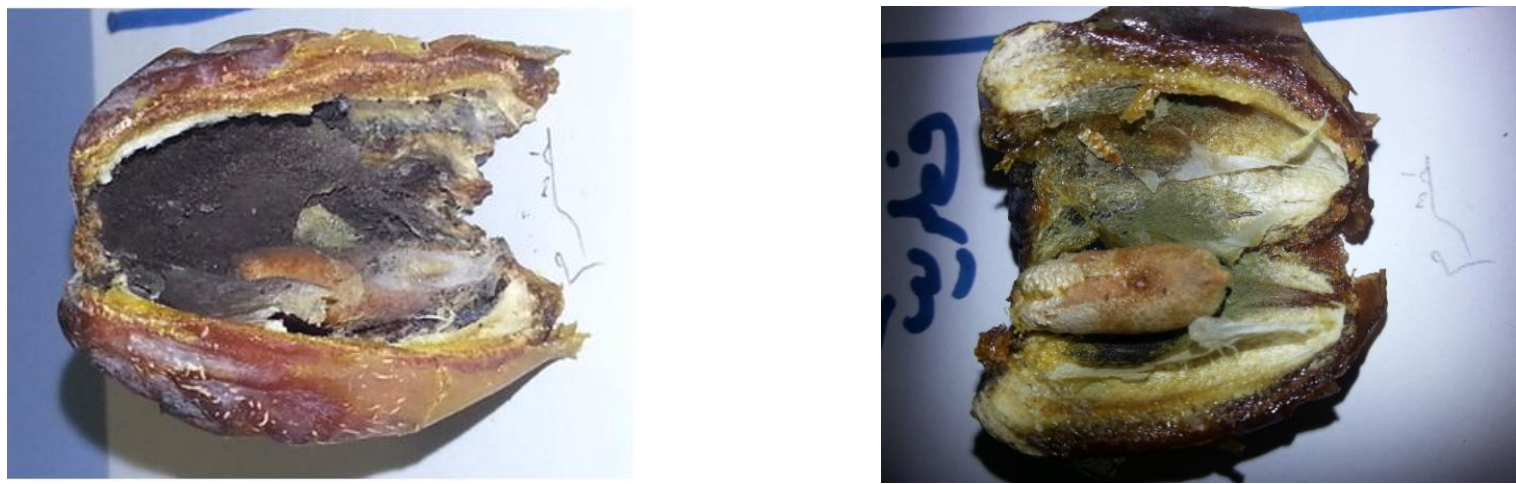

Pathological Disorders of Dates CaUSEd by Fungi 

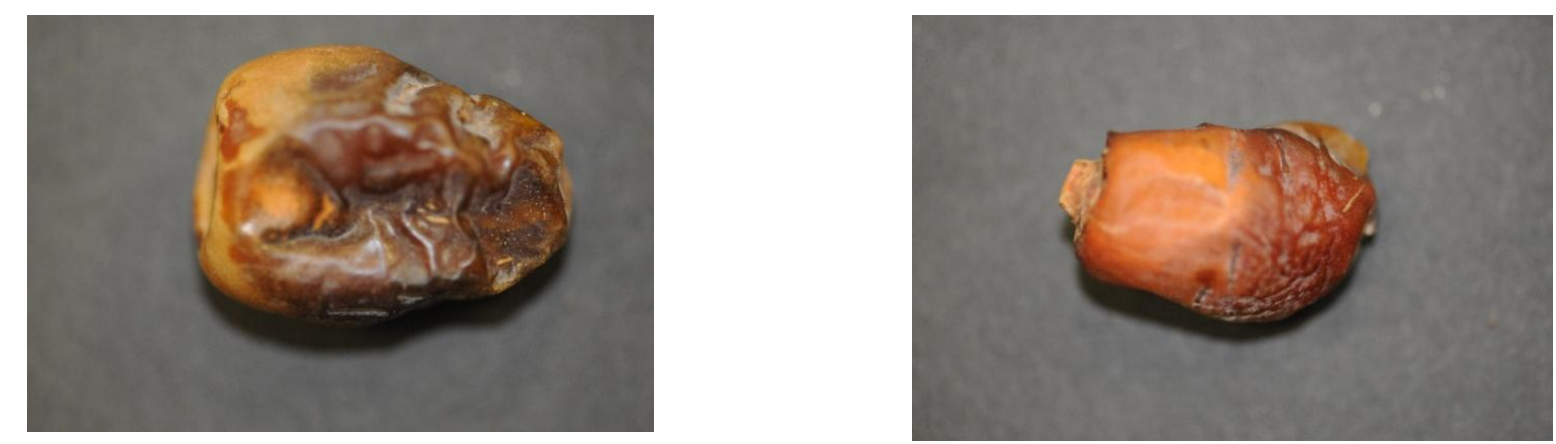

MITE DISORDERS OF DATES
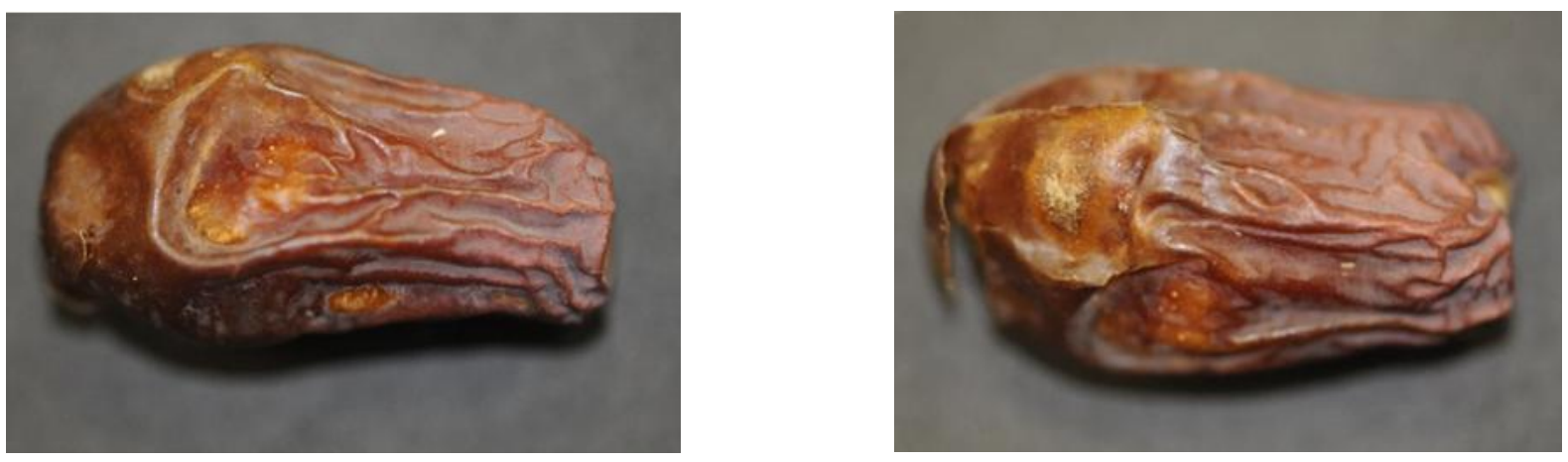

\section{PhySiOlOGiCAL Disorders OF DATES}
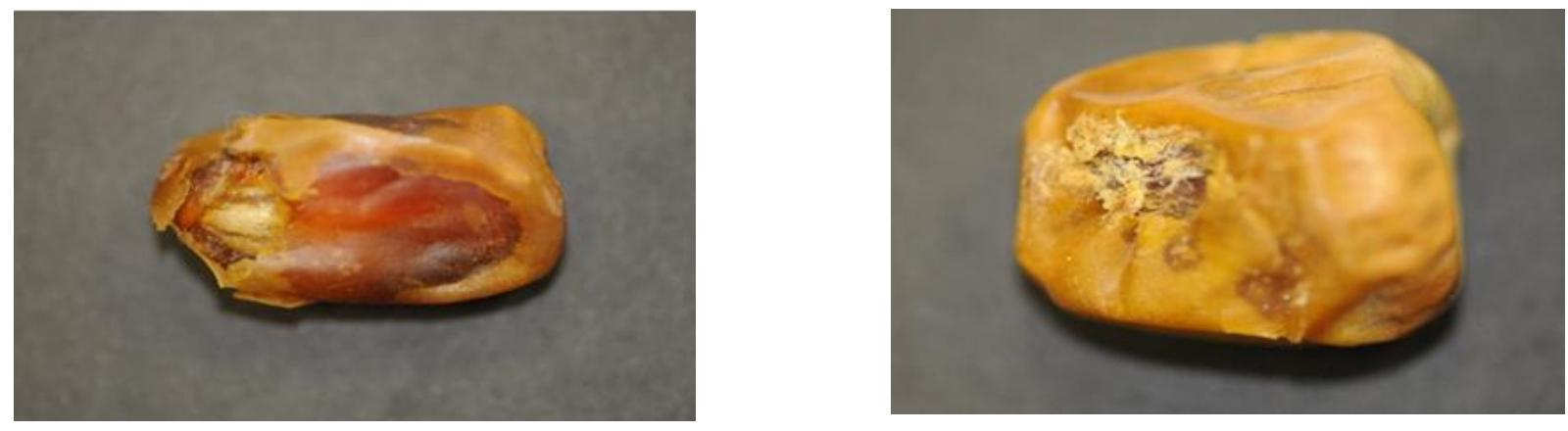

BIRD DISORDERS OF DATES
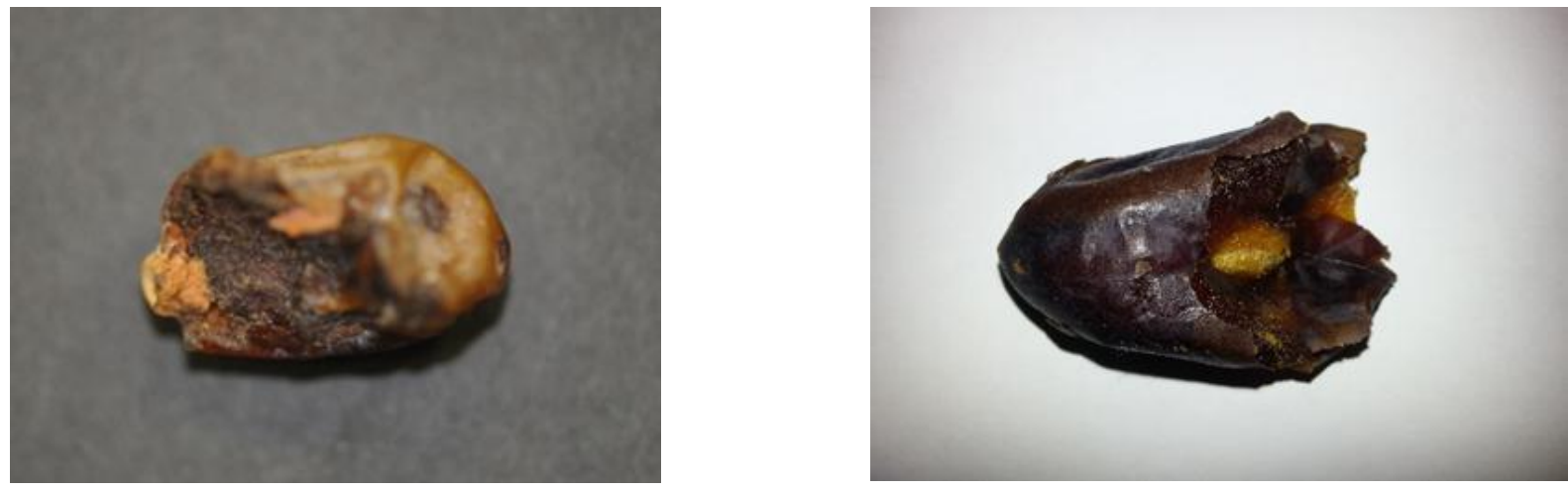

MECHANiCAL Disorders OF DATES

Figure 1: Pest Infestation, Physiological and Non-Pathological Disorders of Dates COLLECTED RANDOMLY FROM ALAHSA DATES FCTORY 
TABLE 6

MEAN OF GENERAL DISORDERS OF VARIOUS DATE VARIETIES RESULTED FROM PEST INFESTATION AND NON-PATHOLOGICAL DISORDERS IN SELECTED VARIETIES IN DIFFERENT REGIONS IN SAUDI ARABIA

\begin{tabular}{|c|c|c|c|}
\hline No. & Variety of dates & Production region & Mean of general disorders (\%) \\
\hline 1. & Khalas & Alahsa & 19.30 \\
\hline 2. & Ruzaze & Alahsa & 21.00 \\
\hline 3. & Shishi & Alahsa & 33.30 \\
\hline 5. & Khudry & Riyadh & 9.18 \\
\hline 9. & Salaj & Riyadh & 12.28 \\
\hline 10. & Berhi & Riyadh & 21.78 \\
\hline 11. & Minifi & Riyadh & 4.07 \\
\hline 12. & Sukkary & Qaseem & 19.86 \\
\hline 13. & Shagra & Qaseem & 14.58 \\
\hline 14. & Berhi & Qaseem & 13.70 \\
\hline 15. & Berhi & Madina & 4.67 \\
\hline 20 & Anbara & Madina & 4.00 \\
\hline 21 & Sukkary & Madina & 4.00 \\
\hline 22 & Khudri & Madina & 5.00 \\
\hline 23 & Safawi & Madina & 2.67 \\
\hline 25 & Ajweh & Madina & 12.19 \\
\hline
\end{tabular}

Source: Field Survey

\section{ECONOMIC AND WATER AND FERTILIZERS LOSS DUE TO DATES LOSS}

Total production of dates in 2014 was about 767 thousand tons. The average wholesale price of dates in the same year was about 11.67 SR/Kg.

The total loss during marketing process of dates was estimated in this study at $7.8 \%$. This means that about 60 thousand tons of dates were lost, at a total value of $\mathrm{SAR}^{1} 698$ thousand annually.

The total number of date palm trees in 2015 was about 28 million trees, out of which about 22.7 million bearing trees. The estimated average number of trees per dunum is about 14.3 trees. The average water consumption of one dunum planted with date palm trees is estimated at 23 thousand cubic meter, then the average loss of water due to dates loss is about 190 thousand cubic meter of irrigation water.

Three main fertilizers are used in date palm production, they are: DAP (compound fertilizer), Urea, and potassium Sulfate, the cost of these fertilizes was estimated at 905 SAR/dunum. The total Area for date Palm was 767 thousand dunums in 2014 (Agricultural Census, 2015), thus the total annual cost of fertilizes in this sector is about SAR 958350, and the values of loss will be, given the above loss weight, 75 thousand SAR.

\section{CONCLUSIONS}

Saudi Arabia is one of the leading countries in the world in producing dates. on the other hand, its exports do not match the large production of this crop.

The level of loss at harvesting time differs from region to region and from variety to another. For example, the loss in khalas variety during harvesting in AlAhsa was about 38\% compared to Ruzaze which had loss at only $7.5 \%$. On the other hand, the loos in Sukkari in Qassim reached about $0.8 \%$ and for Segei $2 \%$.

The level of waste during the marketing phase differs from region to region and from from to variety to other variety, for example, the percentage of loss in most of the selected varieties in Qasim was5-10\%. On the other hand, the majority level of waste of Khalas variety in Qasim was about 5-10\% while in AlAhsa was less than 5\%. The source of loss in Sukkari variety caused by small size constituted one third of the sources for loss while in Riyadh, cuts and browses constituted two thirds of the cause of loss. The small size of Berhi in Qasim constituted about one half of loss causes while cuts and prowess constituted about half the loss causes in Riyadh. The insects were the major cause of loss in Alahsa for Khalas variety (87\%).

\footnotetext{
${ }^{1} 1 \mathrm{US} \$=3.75$ SAR (Saudi Arabia Rial)
} 
Moreover, insects were the major causes of loss in Khudry in Qasim (60\%). The study also found that pest infestation and non-pathological damages of dates were relatively high, reaching $12.19 \%$ in dates of Saudi Arabia at both level, either dates which the government buying from farmers through national date factories or dates commercially available at dates retail marketing respectively.

The average water consumption of one dunum planted with date palm trees is estimated at 23 thousand cubic meter, then the estimated average loss of water due to dates loss is about 190 thousand cubic meter of irrigation water.

The main problems that faced the study team was the absence of landlords which made it difficult to get information from the workers who do not know the detailed needed information.

\section{RECOMMENDATIONS}

The study recommends the following:

- $\quad$ Proposed program to reduce the loss at harvest is as follows:

- Increase the Awareness of date palm growers in areas that recorded high rates of loss such as Al-Ahsa area with the best agricultural operations to maintain them, as well as improving quality, which helps to increase the net yield and thus increase the interest of date producers in that region.

- Decrease the level of loss during harvesting through using good husbandry practices, mainly irrigation and fertilization. In addition, we recommend for the farmers to use nets to protect the fruits from birds, insects, and mites.

- Conduct awareness field days. The Date Palm Center of Excellence at King Faisal University is currently establishing field days in collaboration with the Agricultural Extension Department, Agricultural Directorate in Al-Ahsa in the different production areas for awareness raising and training farmers to improve the quality of dates and reduce losses.

- $\quad$ Add proper quantities of Potassium and calcium fertilizers at the recommended periods, this will affect fruits ripening.

- Implement best management for pests that attack dates and non-pathological damages, (e.g. mechanical, physiological) under pre- and post-harvesting conditions is the key element to reduce such dates disorder.

- $\quad$ Conduct proper fumigation for the stored dates to reduce loss during storing the dates' fruits.

- $\quad$ Dates sector need quality certificates, including quality and good farming practices known as (Global GAP), as well as organic farming, which is part of good agricultural practices.

\section{ACKNOWLEDGMENT}

Researchers offer sincere thanks and appreciation to King Abdul Aziz City for Science and Technology for the acceptance of funding of the project "Assessment of Post-Harvest Loss for Date Palms in the Kingdom of Saudi Arabia-Causes and Solutions", grant No. AT. 34-138, which is expected to be beneficial for the date palm sector in Saudi Arabia.

\section{REFERENCES}

[1] Abo-El-Saad M, Aleid S, Al-Ajlan A, Alhudaib K. 2012. Methyl Bromide Alternatives to Control Ephestia cautella (Walker). Final technical report. 43-87.

[2] Abo-El-Saad M, Elshafie HA, Al Ajlan AM, Bou-Khowh IA. 2011. Non-Chemical Alternatives to Methyl Bromide against Date Moth, Ephestia cautella (Walker) (Lepidoptera; Pyralidae): Microwave and Ozone. Agri Biol J North Amer (8): 1222-31.

[3] Abo-El-Saad, M. and H.A.F. El Shafie. 2013. Insect Pests of stored dates and Their Management. In: Dates: postharvest science, processing technology and health benefits (eds, M.Siddiq, S. Al-Eid and A. Kader) John Wiley \& Sons Ltd.: 81-104.

[4] Al-Qurash, A., Awad, A. and Elsayed, M. 2012. Pre-Harvest Fruit Drop, Bunch Weight and Fruit Quality of 'Rothana' and 'Ghur' Date Palm Cultivars as Affected by Some Growth Regulators under Hot Arid Conditions. American-Eurasian J. Agric. \& Environ. Sci., 12 (6): 781-789, 2012. ISSN 1818-6769. (C IDOSI Publications, DOI: 10.5829/idosi.aejaes.2012.12.06.1742

[5] Authority of Statistics, 2015, Detailed Results of the Agricultural Census. Kingdom of Saudi Arabia.

[6] Beretta, C., Stoessela, F., Baierb, U., and Hellwega, S. (2013). Quantifying food losses and the potential for reduction in Switzerland. Elsevier, Volume 33, Issue 3, March 2013, Pages 764-773.

[7] FAOSTAT. (2015). Food and Agricultural Organization of the United Nations.

[8] Kader, A. and Hussein, A. (2009). Harvesting and post-harvest handling of dates. ICARDA, Aleppo, Syria. (iv). 15 pp. 
[9] Kader, A. (2012). Postharvest Technology of Horticultural Crops (3rd Edition).

[10] Kitinoja, L. (2016). "Innovative Approaches to Food Loss and Waste Issues," Frontier Issues Brief submitted to the Brookings Institution's Ending Rural Hunger project.

[11] Rosegrant, M., Magalhaes, E., and Mason-D'Croz, D. (2016). Returns to Investment in Reducing Postharvest Food Losses and Increasing Agricultural Productivity Growth. Selected Paper prepared for presentation at the 2016 Agricultural \& Applied Economics Association Annual Meeting, Boston, Massachusetts, July 31-August 2. 